\title{
Études/Inuit/Studies
}

\section{Perspectives inuit et qallunaat: points de vue en interaction}

\section{Frédéric Laugrand et Jarich Oosten}

Volume 26, numéro 1, 2002

Perspectives inuit et qallunaat : points de vue en interaction

Inuit and Qallunaaq perspectives: Interacting points of view

URI : https://id.erudit.org/iderudit/009270ar

DOI : https://doi.org/10.7202/009270ar

Aller au sommaire du numéro

Éditeur(s)

Association Inuksiutiit Katimajiit Inc.

ISSN

0701-1008 (imprimé)

1708-5268 (numérique)

Découvrir la revue

Citer cet article

Laugrand, F. \& Oosten, J. (2002). Perspectives inuit et qallunaat: points de vue en interaction. Études/Inuit/Studies, 26(1), 9-15.

https://doi.org/10.7202/009270ar d'utilisation que vous pouvez consulter en ligne.

https://apropos.erudit.org/fr/usagers/politique-dutilisation/ 


\section{Perspectives inuit et qallunaat: points de vue en interaction}

\section{Sous la direction de Frédéric Laugrand et Jarich Oosten}

La seconde moitié du XXe siècle et le début du XXIe ont été marqués par l'émergence et la prise en considération des perspectives inuit sur la nature et le futur de leurs propres sociétés. Pendant longtemps, en effet, les perspectives des Qallunaat (littéralement les «grands sourcils,» soit les non-Inuit) ont dominé les discours académiques. Aujourd'hui les chercheurs réalisent de plus en plus l'énorme potentiel d'une meilleure coopération entre les Inuit et les Qallunaat, ainsi que la pertinence d'une interaction entre ces différentes perspectives, afin de mieux comprendre la culture et la société inuit. Les efforts pour faire reconnaître l'importance des perspectives inuit n'ont pas tous abouti, mais le succès politique des Inuit dans l'acquisition de plus de contrôle sur leurs sociétés a grandement contribué à ce processus.

La lutte qu'ont menée les Inuit pour acquérir un meilleur pouvoir décisionnel et choisir eux-mêmes les orientations politiques concernant leurs territoires et leurs traditions a été un trait dominant de leur vie politique durant les cinquante dernières années. Les revendications pour l'autodétermination sont à l'origine de la création d'une forme avancée de gouvernement autonome au Groenland et, plus récemment, de la formation d'un nouveau territoire dans l'Arctique canadien, le Nunavut, inauguré le $1^{\text {er }}$ avril 1999.

Dans le domaine de l'économie, les Inuit ont développé des approches qui tiennent compte des conditions écologiques et sociologiques spécifiques à l'Arctique. Un bon exemple est le succès du concept de «savoirs autochtones,» «savoirs traditionnels» ou «savoir écologique traditionnel» (mieux connu sous l'acronyme TEK en anglais). Ces questions sont liées à des débats de fond concernant l'articulation des perspectives locales et globales, la question de l'éthique et de la propriété intellectuelle, les problèmes sur l'identité et la nature ontologique du savoir, ainsi que l'intégration des savoirs indigènes dans les processus de décision.

Dans le domaine de la culture, les Inuit ont insisté sur des points essentiels comme le maintien de la diversité culturelle, la conservation du savoir des aînés, ainsi que celle des langues et dialectes inuit. Au Nunavut, le succès actuel de la notion de Inuit qaujimajatuqangit («savoirs de longue date conservant une pertinence sociale») peut être considéré comme un bon exemple de toutes ces tendances qui fusionnent et influencent les politiques dans bien des domaines, de la langue au droit.

Les efforts des Inuit pour mettre en valeur leurs propres perspectives et approches concernant leur culture et leur société affectent profondément les habitudes 
académiques. Au cours des trente dernières années, de nombreux chercheurs ont développé un intérêt certain pour une meilleure compréhension des perspectives et des traditions inuit. Plusieurs livres et articles publiés du Groenland à l'Alaska contribuent ainsi à mieux faire connaître la diversité des traditions et des perspectives inuit. Les Inuit ne sont plus représentés comme les sujets passifs d'un processus de modernisation à sens unique. Les chercheurs les décrivent plutôt comme des agents actifs qui ont initié bien des transformations socioculturelles et ont répondu avec créativité aux changements rapides causés par leurs contacts fréquents avec les Qallunaat.

L'anthropologie elle-même prend de plus en plus la forme d'un dialogue. La confiance dans l'objectivité des théories et des méthodes anthropologiques s'est dégradée. En accordant plus d'attention aux perspectives inuit, les anthropologues se rendent compte des limites de leurs propres perspectives. Une réorientation s'est opérée, si bien que l'accent ne porte plus sur la description «objective» des réalités mais sur les questions de traduction, d'herméneutique et d'interprétation. L'intégration de la technologie moderne, de la religion chrétienne et de l'économie globale conduisent à de nouvelles synthèses qui associent des traditions occidentales et inuit. Ann Fienup-Riordan (2000: 49) a noté cette évolution: «Plutôt que d'essayer de représenter les autres, de décrire 'le point de vue autochtone' comme une fin en soi, le projet ethnographique tend de plus en plus à essayer de faire comprendre comment les peuples indigènes se présentent chez eux et à l'extérieur» (notre traduction).

Le développement récent de la notion d'Inuit qaujimajatuqangit (mieux connue sous l'acronyme IQ) reflète ce souhait des Inuit de conserver leurs traditions culturelles et leurs identités. La notion même d'Inuit qaujimajatuqangit est le produit d'un processus historique. Elle implique une étude du changement et de la variation dans le temps et dans l'espace. Une combinaison accrue des sources d'archives et d'entrevues avec des aînés fournit également une représentation complexe et différenciée des traditions et savoirs inuit. La recherche anthropologique sur le IQ ne pourra se faire qu'en reconnaissant la valeur des perspectives inuit et en partenariat avec les Inuit.

Dans ce numéro thématique de la revue Études/Inuit/Studies, nous nous concentrons sur les perspectives inuit et qallunaat en tant que points de vue en interaction. De toute évidence, de nombreuses problématiques pourraient être explorées sous cet angle. En prenant ici l'Arctique canadien comme scène principale (un article porte sur le Groenland), nous avons choisi d'accorder une attention particulière aux idées, aux valeurs, aux perceptions, aux représentations et aux aspects religieux de la transmission des savoirs et des traditions.

La première partie de ce numéro comprend cinq articles rédigés par des chercheurs du milieu académique qui, à partir d'angles différents, présentent leurs points de vue sur les perspectives des Inuit et déconstruisent certaines représentations traditionnelles provenant des Qallunaat. Jarich Oosten et Frédéric Laugrand discutent des principaux résultats d'un atelier de travail qui portait sur «L'intégration de l'Inuit Qaujimajatuqangit dans les méthodes de contrôle social» et qui eut lieu à Rankin Inlet en juillet 2000. Ils décrivent un contexte ethnographique relativement nouveau et original construit à partir de leur expérience précédente d'enseignement au Nunavut 
Arctic College à Iqaluit. Grâce à une collaboration étroite entre des chercheurs du milieu académique et des aînés inuit, l'interaction entre les participants fut particulièrement fructueuse à propos de l'angakkuuniq (le chamanisme), un sujet encore très sensible dans l'Arctique. En prenant la nuit comme objet anthropologique et en considérant plusieurs témoignages d'Inuit à ce propos, Guy Bordin déconstruit une vision occidentale particulièrement ancrée dans nos traditions - celle de la longue nuit hivernale versus le bref été lumineux - montrant ainsi que cette idée a peu à voir avec le vécu et les représentations des Inuit. Bordin explore plusieurs dimensions de la nuit inuit dans lesquelles il repère un certain nombre de paradoxes. Adoptant une perspective ethnolinguistique, Vladimir Randa traite de la logique de la construction et de l'organisation des zoonymes dans la langue des Inuit de la Terre de Baffin. Il démontre que la ressemblance morphologique est clairement à l'origine des relations qui sont matérialisées par la biais de la dérivation lexicale. Cornelius Remie et Jarich Oosten présentent ensuite une analyse historique du processus de transition des Inuit vers le christianisme tel qu'il se déroula à Pelly Bay entre 1935 et 1950. En utilisant un corpus important d'archives écrites, les auteurs montrent le rôle actif des Inuit dans la naissance de cette fervente communauté catholique. Finalement, dans un article de linguistique, Anna Berge déconstruit l'expression du discours indirect en groenlandais de l'ouest.

La deuxième partie de ce numéro (la section «Documents») comprend trois articles dont les auteurs sont d'anciennes élèves inuit du Nunavut Arctic College (Iqaluit) qui donnent leurs perspectives et leurs points de vue sur des aspects-clés des traditions inuit. Le premier article décrit la place et le rôle du phoque dans la culture des Inuit. Aaju Peter, Myna Ishulutak, Julia Shaimaiyuk, Jeannie Shaimaiyuk, Nancy Kisa, Bernice Kootoo et Susan Enuaraq expliquent comment le phoque apporte aux Inuit beaucoup plus que de la nourriture et des vêtements, dans la mesure où ce n'est qu'à travers son partage et sa consommation qu'ils affirment conserver leur force physique et mentale. En adoptant une perspective holiste, cette contribution montre l'importance du phoque dans l'identité inuit moderne. L'article de Bernice Kootoo explore les perspectives contemporaines concernant les sages-femmes. Bien que les Inuit disposaient de leurs propres traditions pour les accouchements - des pratiques transmises de générations en générations - celles-ci commencèrent à disparaitre avec l'arrivée du gouvernement et des hôpitaux dans le Nord canadien. De nos jours, quelques aînés, et visiblement l'auteure, pensent que certaines de ces traditions devraient être conservées pour les générations futures. Finalement, Vera Arnatsiaq apporte sa contribution au débat délicat et très actuel sur la façon dont l'inuktitut devrait être enseigné dans les écoles élémentaires d'aujourd'hui. Elle se base ici sur ses propres expériences d'enseignante à l'école élémentaire Attaguttaaluk, à Igloolik.

De nos jours, les Inuit du Nunavut, et surtout les jeunes gens, affirment qu'il est urgent de recueillir le savoir des ainés en accordant une attention toute particulière à sa richesse et aux multiples variations locales. Nous espérons sincèrement que ce numéro sera non seulement d'intérêt pour les lecteurs de la revue, mais aussi une invitation adressée à tous pour lancer ou approfondir des projets en collaboration avec les Inuit. 


\section{Référence}

FIENUP-RIORDAN, Ann

2000 Hunting Tradition in a Changing World. Yup'ik Lives in Alaska Today, New Brunswick, Rutgers University Press. 


\section{Inuit and Qallunaaq perspectives: Interacting points of view}

\section{Directed by \\ Frédéric Laugrand and Jarich Oosten}

The second half of the XXth century and the beginning of the XXIth century are marked by the emergence and articulation of Inuit perspectives on the nature and future of their own societies. For a long time, Qallunaaq (literally "the big high brows," hence the non-Inuit) perspectives have dominated academic discourses. Today, scholars become increasingly aware of the enormous potential of co-operation between Inuit and Qallunaat, and of interaction between Inuit and Qallunaaq perspectives, to gain a better understanding of Inuit culture and society. The struggle for recognition of the importance of Inuit perspectives is still incomplete, but the political success of Inuit in acquiring more control over their societies has greatly contributed to the process.

The struggle of Inuit to make their own policies and decisions concerning their land and traditions has been a dominant feature of Inuit political life over the last fifty years. Claims for self-determination resulted in an advanced form of self-government in Greenland and, more recently, in the creation of Nunavut as a Canadian arctic territory in its own right, on April 1, 1999.

In the field of economics, Inuit developed approaches that fitted the specific ecological and sociological conditions of the Arctic. A case in point is the success of a concept that has been variously called aboriginal knowledge, traditional knowledge, or TEK (Traditional Ecological Knowledge). These approaches have been linked to major debates concerning the articulation between local and global perspectives, the question of ethics and intellectual property, problems of identity and the ontological nature of knowledge, the integration of indigenous knowledge in local decision-making processes, etc.

In the field of culture, Inuit have stressed major points such as the maintenance of cultural diversity, the preservation of the knowledge of the elders, as well as that of Inuit languages and dialects. In Nunavut, the current success of the notion of Inuit qaujimajatuqangit ("Inuit long-standing knowledge") can be considered as a good example of all these trends merging together and influencing politics in various aspects from language to law policies.

The efforts of Inuit to develop their own perspectives and approaches to Inuit culture and society deeply affect academic traditions. Especially in the last 30 years, many researchers have developed a keen interest in a better understanding of Inuit perspectives and traditions. Many books and articles have been published from Greenland to Alaska that contribute to a better knowledge of the diversity of Inuit traditions and perspectives. Inuit are no longer represented as the passive subjects of a 
one-sided process of modernization. Now, scholars focus on Inuit as active agents initiating changes within their culture and society and responding creatively to the rapid changes caused by their extensive and multifaceted contacts with Qallunaat.

Anthropology itself is turning into a dialogue. The confidence in the objectivity of anthropology's theories and methods is rapidly eroding. By carefully recording Inuit perspectives, anthropologists become better aware of the limitations of their own perspectives. The emphasis shifts from «objective» description to translation, hermeneutics and interpretation. The integration of modern technology, Christian religion and global economics leads to new syntheses of Western and Inuit traditions. As stated by Ann Fienup-Riordan (2000: 49): "Instead of anthropology seeking to represent others, to describe 'the native point of view' as an end in itself, increasingly the ethnographic project is to help understand how indigenous people present themselves both at home and abroad."

The recent development of the notion of Inuit qaujimajatuqangit (IQ) reflects the wish of Inuit to retain their cultural traditions and identities. Obviously, the notion of Inuit qaujimajatuqangit is the product of a historical process. It implies a study of change and variation in time and space. Combination of archival sources with oral accounts of elders provides a complex and differentiated representation of Inuit traditions and knowledge. Anthropological research of IQ can only proceed by acknowledging the value of Inuit perspectives and in partnership with Inuit.

In this thematic issue of Études/Inuit/Studies, we focus on Inuit and Qallunaaq perspectives as interacting points of view. Obviously, many issues could be explored from this angle. Taking the Canadian Arctic as the main scene (one paper is dealing with Greenland), we devote particular attention to ideas, values, perceptions, representations, religious aspects and the transmission of knowledge and traditions.

The first part of the volume includes five papers signed by academic researchers that shed light on the Inuit perspectives from various angles and even deconstruct some of the traditional representations brought by Qallunaat. Jarich Oosten and Frédéric Laugrand discuss the main results of a workshop on Integrating Inuit Qaujimajatuqangit into Methods of Social Control that was held in Rankin Inlet in July 2000. They present this new and original ethnographical setting built on their teaching experiences at Nunavut Arctic College in Iqaluit. Based on a close collaboration between academic researchers and Inuit elders, the interaction among participants was particularly fruitful on angakkuuniq, a very sensitive topic in the Arctic. Taking the night as an anthropological object and considering many testimonies provided by the Inuit, Guy Bordin deconstructs a very traditional Western vision - the long winter night versus the brief bright summer - showing that this idea has little to do with Inuit life and representations. On the contrary, Bordin follows the many dimensions of the Inuit night in which he sees a number of paradoxes. Adopting an ethno-linguistic perspective, Vladimir Randa explores the logic in the construction and organization of zoonyms in Baffin Inuit language. He demonstrates that morphological resemblance is clearly at the origin of relationships which are materialized by means of lexical derivation. Cornelius Remie and Jarich Oosten provide an historical analysis of the 
Inuit transition to Christianity as it happened in Pelly Bay between 1935 and 1950 . Using a major corpus of written archives, the authors induce the active role of the Inuit in the birth of a fervent Catholic community. Finally, in her linguistic paper, Anna Berge deconstructs the expression of indirect discourse in West Greenlandic.

The second part of the volume (the "Documents" section) presents three papers signed by a group of former Inuit students at Nunavut Arctic College, who give their own perspectives and interpretations on key aspects of Inuit traditions. The first paper deals with the place and role of the seal in Inuit cultural traditions. Aaju Peter, Myna Ishulutak, Julia Shaimaiyuk, Jeannie Shaimaiyuk, Nancy Kisa, Bernice Kootoo and Susan Enuaraq explain how the seal provides Inuit with more than just food and clothes, as it is through sharing and eating seal that Inuit keep their physical and mental strength. Adopting a holistic perspective, their contribution shows how important the seal remains for contemporary Inuit identity. The paper prepared by Bernice Kootoo explores modern Inuit perspectives on Inuit midwifery. The Inuit had their own tradition of giving birth that was handed down from generation to generation, but these very rich traditions started to erode when the Government and the hospitals arrived in the North. Nowadays, some of the elders, and clearly here the author, feel that some of these traditions should be retained for the future. Finally, Vera Arnatsiaq contributes to the contemporary and sensitive issue of how to teach Inuktitut in elementary schools today. In that respect, she relies on her own experience at Attaguttaaluk elementary school in Igloolik.

At a time when the Inuit and many young people from Nunavut claim that there is an urgent need to record knowledge from the elders with due attention to its richness and local variations, we sincerely hope that this issue will not only be of interest to the readers but also an invitation for all to bring such collaborations further.

\section{Reference}

FIENUP-RIORDAN, Ann

2000 Hunting Tradition in a Changing World. Yup'ik Lives in Alaska Today, New Brunswick, Rutgers University Press. 